Article

\title{
Bioactive Benzofuran Derivatives from Cortex Mori Radicis, and Their Neuroprotective and Analgesic Activities Mediated by mGluR $_{1}$
}

\author{
Ya-Nan Wang ${ }^{1,+}$, Mao-Feng Liu ${ }^{1,+}$, Wei-Zhen Hou ${ }^{1}$, Rui-Ming Xu ${ }^{1}$, Jie Gao ${ }^{2}$, An-Qi Lu ${ }^{1}$, \\ Mei-Ping Xie ${ }^{1}$, Lan Li ${ }^{1}$, Jian-Jun Zhang ${ }^{1}$, Ying Peng ${ }^{1}$, Li-Li Ma ${ }^{3}$, Xiao-Liang Wang ${ }^{1}$, \\ Jian-Gong Shi ${ }^{1}$ and Su-Juan Wang ${ }^{1, *}$ \\ 1 State Key Laboratory of Bioactive Substance and Function of Natural Medicines, Institute of Materia Medica, \\ Chinese Academy of Medical Sciences \& Peking Union Medical College, Beijing 100050, China; \\ wangyanan@imm.ac.cn (Y.-N.W.); 13241468601@163.com (M.-F.L.); houweizhen@imm.ac.cn (W.-Z.H.); \\ rmxu@imm.ac.cn (R.-M.X.); angellu@imm.ac.cn (A.-Q.L.); xiemeiping2016@sina.com (M.-P.X.); \\ lilan@imm.ac.cn (L.L.); jjzhang@imm.ac.cn (J.-J.Z.); ypeng@imm.ac.cn (Y.P.); \\ wangxl@imm.ac.cn (X.-L.W.); shijg@imm.ac.cn (J.-G.S.) \\ 2 GRU Cancer Center, Augusta University, Augusta, GA 30912, USA; jgao@augusta.edu \\ 3 Editorial Department, Shenyang Pharmaceutical University, Shenyang 110016, China; \\ malili022406@sina.com \\ * Correspondence: sujuanwang@imm.ac.cn; Tel.: +86-10-83154789 \\ + These authors contributed equally to this study.
}

Academic Editor: Isabel C. F. R. Ferreira

Received: 30 December 2016; Accepted: 31 January 2017; Published: 8 February 2017

\begin{abstract}
Four new benzofuran-type stilbene glycosides and 14 known compounds including 8 benzofuran-type stilbenes and 6 flavonoids were isolated from the traditional Chinese medicine, Cortex Mori Radicis. The new compounds were identified as ( $9 R$ )-moracin P $3^{\prime}-O-\alpha$-L-arabinopyranoside (1), (9R)-moracin P 9-O- $\beta$-D-glucopyranoside (2), (9R)-moracin P $3^{\prime}-O-\beta$-D-glucopyranoside (3), and $(9 R)$-moracin O 10-O- $\beta$-D-glucopyranoside (4) based on the spectroscopic interpretation and chemical analysis. Three benzofuran-type stilbenes, moracin O (5), R (7), and P (8) showed significant neuroprotective activity against glutamate-induced cell death in SK-N-SH cells. In addition, moracin $\mathrm{O}(5)$ and $\mathrm{P}(8)$ also demonstrated a remarkable inhibition of the acetic acid-induced pain. The molecular docking with metabotropic glutamate receptor $1\left(\mathrm{mGluR}_{1}\right)$ results indicated that these neuroprotective benzofuran-type stilbenes might be the active analgesic components of the genus Morus, and acted by mediating the $\mathrm{mGluR}_{1}$ pathway.
\end{abstract}

Keywords: benzofuran-type stilbenes; neuroprotection; analgesia; Cortex Mori Radicis

\section{Introduction}

Cortex Mori Radicis, the root bark of some Morus species (e.g., M. alba, M. mongolica, M. cathayana, and M. australis) have been used in traditional Chinese medicine as an antidiabetic, diuretic, and expectorant agent. Many compounds were identified from Morus plants, such as Diels-Alder-type adducts, stilbenes, flavonoids, and alkaloids. Their antioxidant [1-3], anti-inflammatory [4,5], antimicrobial [6-9], anticarcinogenic [10-12], and antidiabetic [13] activities were reported frequently. Recently, the structures and bioactivities of polyphenols from Morus plants [14] and bioactive benzofurans [15] were reviewed. It should be noted that the extracts of some twigs [16], leaves [17], or root barks [18] of Morus species were used to relieve pain in folk medicine. To the best of our knowledge, only two compounds from genus Morus, cis-mulberroside A [19] and morusin [20], have 
been reported with analgesic activity to date, which is related to the traditional antirheumatic usage of Cortex Mori Radicis.

L-Glutamate is the major excitatory neurotransmitter in the central nervous system (CNS) and glutamate-mediated excitotoxicity plays a crucial role in neurodegenerative disorder, particularly in Parkinson's disease, Alzheimer's disease, epilepsy, spinal cord trauma, and ischemic stroke. As glutamate receptors are also found in peripheral tissue, they may be implicated in persistent or chronic pain, including inflammatory or joint-related pain (e.g., rheumatoid arthritis, osteoarthritis) and neuropathic pain resulting from injury and/or diseases of central (e.g., spinal cord injury) or peripheral nerves (e.g., diabetic neuropathy, radiculopathy) [21,22].

Neuroprotective effect of stilbenes, including piceid and resveratrol, has been widely reported [23], but the applications of benzofuran stilbene on CNS diseases [24] and analgesia were rarely studied. In this paper, we report four new benzofuran stilbene glycosides (1-4) and the neuroprotective and analgesic activities of their aglycones. Three benzofuran stilbenes showed significant protective activities against glutamate-induced neurotoxicity. Correspondingly, they also exhibited remarkable analgesic activities by inhibition of the acetic acid-induced pain. Structural determinations of compounds were carried out on the basis of spectroscopic data analyses. The primary action mechanism of neuroprotection and analgesia was also discussed with the help of the molecular docking with metabotropic glutamate receptor $1\left(\mathrm{mGluR}_{1}\right)$.

\section{Results and Discussion}

\subsection{Structural Analysis}

Eighteen compounds, including four new (1-4) and eight known (5-12) stilbenes and six known flavonoids (13-18), were isolated from the EtOAc-soluble fraction of Cortex Mori Radicis (Figure 1). The known compounds were elucidated as moracin $\mathrm{O}$ (5) [25], oxyresveratrol (6) [26], moracin $\mathrm{R}$ (7) [27], moracin P (8) [25], mulberroside C (9) [28], wittifuran E (10) [28], isomulberrofuran G (11) [29], mulberrofuran G (12) [30], norartocarpetin (13) [31], morin (14) [32], morusin (15) [33], sanggenon C (16) [34], sanggenon D (17) [35], and cathayanin B (18) [36] by comparison with spectroscopic data in the literatures.

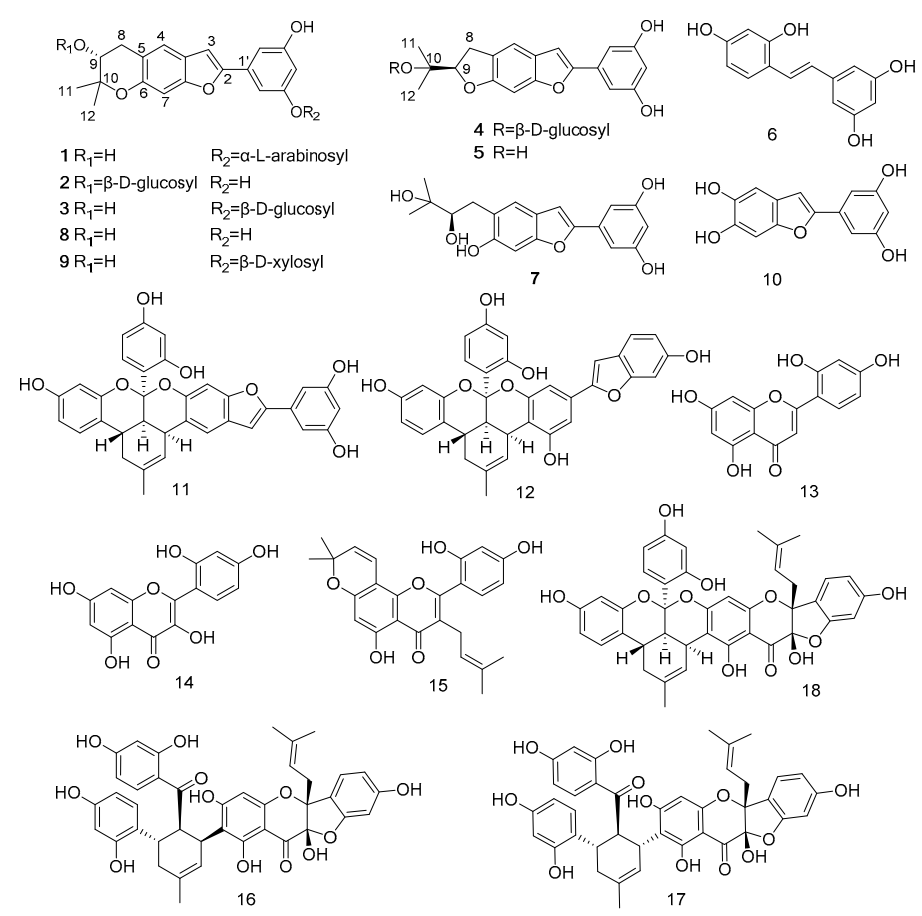

Figure 1. Structures of isolated compounds from Cortex Mori Radicis. 
Compound 1, purified as a brown powder, had the molecular formula of $\mathrm{C}_{24} \mathrm{H}_{26} \mathrm{O}_{9}$ as established by HRESIMS $m / z 459.1663[\mathrm{M}+\mathrm{H}]^{+}$(calcd for $\mathrm{C}_{24} \mathrm{H}_{27} \mathrm{O}_{9}{ }^{+}, 459.1650$ ). The ${ }^{1} \mathrm{H}-\mathrm{NMR}$ spectrum (Table 1) demonstrated a 2-arylbenzofuran skeleton with three meta-aromatic protons at $\delta_{\mathrm{H}} 6.91$ $\left(1 \mathrm{H}, \mathrm{d}, J=2.1 \mathrm{~Hz}, \mathrm{H}-2^{\prime}\right), 6.89\left(1 \mathrm{H}, \mathrm{d}, J=2.1 \mathrm{~Hz}, \mathrm{H}-6^{\prime}\right)$, and $6.43\left(1 \mathrm{H}, \mathrm{t}, J=2.1 \mathrm{~Hz}, \mathrm{H}-4^{\prime}\right)$; two para-aromatic protons at $\delta_{\mathrm{H}} 7.29(1 \mathrm{H}, \mathrm{s}, \mathrm{H}-4), 6.93(1 \mathrm{H}, \mathrm{s}, \mathrm{H}-7)$, and one singlet at $\delta_{\mathrm{H}} 7.17(1 \mathrm{H}, \mathrm{s}$, $\mathrm{H}-3)$. Two gem-dimethyl signals at $\delta_{\mathrm{H}} 1.31(3 \mathrm{H}, \mathrm{s}, \mathrm{H}-11)$, and $1.18(3 \mathrm{H}, \mathrm{s}, \mathrm{H}-12)$, one methylene at $\delta_{\mathrm{H}}$ $3.02(1 \mathrm{H}, \mathrm{dd}, J=16.4,6.0 \mathrm{~Hz}, \mathrm{H}-8 \mathrm{a})$, and $2.72(1 \mathrm{H}, \mathrm{dd}, J=16.4,7.0 \mathrm{~Hz}, \mathrm{H}-8 \mathrm{~b})$ indicated the presence of an isoprenyl fragment. The remaining signals at $\delta_{\mathrm{H}} 4.85\left(1 \mathrm{H}, \mathrm{d}, J=6.7 \mathrm{~Hz}, \mathrm{H}-1^{\prime \prime}\right)$ and $\delta_{\mathrm{H}} 2.60-3.80$ were assigned to a pentose moiety. Besides the five pentosyl signals, the ${ }^{13} \mathrm{C}$-NMR spectrum (Table 2) confirmed the presence of isoprenylated 2-arylbenzofuran skeleton including 14 olefinic carbons and 5 alkyl carbons. Further, HMBC correlations between $\mathrm{H}_{2}-8\left(\delta_{\mathrm{H}} 3.02,2.72\right)$ and $\mathrm{C}-4\left(\delta_{\mathrm{C}} 120.9\right)$ and $\mathrm{C}-6$ $\left(\delta_{C} 151.2\right) ; H-9\left(\delta_{H} 3.67\right)$ and $C-5\left(\delta_{C} 117.2\right)$ were observed, and these data elucidated the aglycone of 1 as moracin P [25]. The linkage of pentose was determined to be at the C-3' position, deduced from the HMBC correlation between $\mathrm{H}-1^{\prime \prime}\left(\delta_{\mathrm{H}} 4.85\right)$ and $\mathrm{C}-3^{\prime}\left(\delta_{\mathrm{C}} 158.8\right)$. In ${ }^{1} \mathrm{H}-\mathrm{NMR}$ spectra, the $\mathrm{H}-4^{\prime \prime}$ of the pentose was a broad singlet and the coupling constants between H-4" and H-5", H-4" and H-3" were less than $4 \mathrm{~Hz}$, indicated that H-4" was equatorial. Subsequent acid hydrolysis identified the pentose as L-arabinose and the aglycone as $(9 R)$-moracin P. The C-4" $\left(\delta_{C} 68.0\right)$ indicated the arabinose was a pyranose [37]. Therefore, the chemical structure of 1 was established as (9R)-moracin P $3^{\prime}-O-\alpha$-L-arabinopyranoside.

The molecular formulas of compounds 2 and 3 were both $\mathrm{C}_{25} \mathrm{H}_{28} \mathrm{O}_{10}$, established by HRESIMS $\left(\mathrm{m} / z 511.1588[\mathrm{M}+\mathrm{Na}]^{+}\right.$, calculated for $\mathrm{C}_{25} \mathrm{H}_{28} \mathrm{O}_{10} \mathrm{Na}^{+}$, 511.1575). Comparing ${ }^{1} \mathrm{H}-\mathrm{NMR}$ and ${ }^{13} \mathrm{C}-\mathrm{NMR}$ spectra (Tables 1 and 2) of compounds 2 and $\mathbf{3}$ with those of compound 1, the structures of 2 and 3 were both identified as moracin P glycosides with a hexose in their structures, and further supported by HMBC analysis. The linkage of sugar in 2 was determined to be at C-9 position, deduced from the HMBC correlation between $\mathrm{H}-1^{\prime \prime}\left(\delta_{\mathrm{H}} 4.33, \mathrm{~d}, J=7.7 \mathrm{~Hz}\right)$ and $\mathrm{C}-9\left(\delta_{\mathrm{C}} 73.4\right)$. The sugar in 3 was connected to $C-3^{\prime}$ position, deduced from the HMBC correlation between $\mathrm{H}-1^{\prime \prime}\left(\delta_{\mathrm{H}} 4.83 \mathrm{~d}, \mathrm{~J}=7.6 \mathrm{~Hz}\right)$ and $C-3^{\prime}\left(\delta_{C}\right.$ 159.1). Subsequent acid hydrolysis identified the aglycone as $(9 R)$-moracin $P$ and the sugar as D-glucose. Therefore, the structures of 2 and $\mathbf{3}$ were established as (9R)-moracin $\mathrm{P}$ 9-O- $\beta$-D-glucopyranoside (2) and (9R)-moracin P 3'-O- $\beta$-D-glucopyranoside (3), respectively.

Table 1. ${ }^{1} \mathrm{H}-\mathrm{NMR}(500 \mathrm{MHz}, \mathrm{J}$ in $\mathrm{Hz})$ spectroscopic data of compounds 1-4 in DMSO- $d_{6}$.

\begin{tabular}{|c|c|c|c|c|}
\hline No. & 1 & 2 & 3 & 4 \\
\hline 3 & $7.17 \mathrm{~s}$ & $7.07 \mathrm{~s}$ & $7.15 \mathrm{~s}$ & $7.07 \mathrm{~s}$ \\
\hline 4 & $7.29 \mathrm{~s}$ & $7.30 \mathrm{~s}$ & $7.27 \mathrm{~s}$ & $7.34 \mathrm{~s}$ \\
\hline 7 & $6.93 \mathrm{~s}$ & $6.94 \mathrm{~s}$ & $6.92 \mathrm{~s}$ & $6.98 \mathrm{~s}$ \\
\hline 8 & $\begin{array}{l}3.02 \mathrm{dd}(16.4,6.0), \\
2.72 \mathrm{dd}(16.4,7.0)\end{array}$ & $\begin{array}{c}3.14 \mathrm{~m}^{\mathrm{b}} \\
2.83 \mathrm{dd}(16.6,6.7)\end{array}$ & $\begin{array}{l}3.01 \mathrm{dd}(16.5,5.2) \\
2.70 \mathrm{dd}(16.5,8.1)\end{array}$ & $\begin{array}{l}3.16 \mathrm{~m}^{\mathrm{c}} \\
3.35 \mathrm{~m}^{*}\end{array}$ \\
\hline 9 & $3.67 \mathrm{dd}(7.0,6.0)$ & $3.95 \mathrm{dd}(6.7,5.9)$ & $3.66 \mathrm{dd}(8.1,5.2)$ & 4.75 t (8.8) \\
\hline 11 & $1.31 \mathrm{~s}$ & $1.34 \mathrm{~s}$ & $1.31 \mathrm{~s}$ & $1.28 \mathrm{~s}$ \\
\hline 12 & $1.18 \mathrm{~s}$ & $1.24 \mathrm{~s}$ & $1.18 \mathrm{~s}$ & $1.21 \mathrm{~s}$ \\
\hline $2^{\prime}$ & $6.91 \mathrm{~d}(2.1)$ & $6.68 \mathrm{~d}(1.5)$ & 6.96 br s & $6.67 \mathrm{~d}(2.0)$ \\
\hline $4^{\prime}$ & $6.43 \mathrm{t}(2.1)$ & $6.21 \mathrm{t}(1.5)$ & $6.44 \mathrm{br} \mathrm{s}$ & $6.21 \mathrm{t}(2.0)$ \\
\hline $6^{\prime}$ & $6.89 \mathrm{~d}(2.1)$ & $6.68 \mathrm{~d}(1.5)$ & 6.88 br s & $6.67 \mathrm{~d}(2.0)$ \\
\hline $1^{\prime \prime}$ & $4.85 \mathrm{~d}(6.7)$ & $4.33 \mathrm{~d}(7.7)$ & $4.83 \mathrm{~d}(7.6)$ & $4.42 \mathrm{~d}(7.8)$ \\
\hline $2 "$ & $3.60 \mathrm{~m}^{\mathrm{a}}$ & $2.94 \mathrm{dd}(8.0,7.7)$ & 3.22 t $(7.6)$ & $2.88 \mathrm{t}(8.2)$ \\
\hline $3^{\prime \prime}$ & $3.49 \mathrm{dd}(8.5,3.2)$ & $3.14 \mathrm{~m}^{\mathrm{b}}$ & 3.27 t (8.5) & $3.16 \mathrm{~m}^{\mathrm{c}}$ \\
\hline $4^{\prime \prime}$ & $3.70 \mathrm{brs}$ & $3.03 \mathrm{t}(9.1)$ & $3.16 \mathrm{t}(9.0)$ & $3.04 \mathrm{t}(8.0)^{\mathrm{d}}$ \\
\hline $5^{\prime \prime}$ & $\begin{array}{c}3.60 \mathrm{dd}(11.2,1.5)^{\mathrm{a}}, \\
3.75 \mathrm{dd}(11.2,3.2)\end{array}$ & $3.14 \mathrm{~m}^{\mathrm{b}}$ & $3.35 \mathrm{~m}$ * & $3.04 \mathrm{~d}(8.0)^{\mathrm{d}}$ \\
\hline $6 "$ & - & $\begin{array}{c}3.68 \mathrm{brd}(11.3), \\
3.43 \mathrm{dd}(11.3,6.2)\end{array}$ & $\begin{array}{l}3.71 \text { br.d (11.4), } \\
3.48 \mathrm{~m}\end{array}$ & $\begin{array}{c}3.35 \mathrm{~m}^{*} \\
3.45 \text { br.d (11.3) }\end{array}$ \\
\hline
\end{tabular}

a-d Signals were overlapped with each other. ${ }^{*}$ Signals were overlapped by water or solvent peak. 
Table 2. ${ }^{13} \mathrm{C}-\mathrm{NMR}$ spectroscopic data of compounds $\mathbf{1 - 4}$ in DMSO- $d_{6}$.

\begin{tabular}{cccccccccc}
\hline Position & $\mathbf{1}^{\mathbf{a}}$ & $\mathbf{2}^{\mathbf{b}}$ & $\mathbf{3}$ & $\mathbf{4}$ & Position & $\mathbf{1}^{\mathbf{a}}$ & $\mathbf{2}^{\mathbf{b}}$ & $\mathbf{3}$ & $\mathbf{4}$ \\
\hline 2 & 154.0 & 153.8 & 154.1 & 154.2 & $1^{\prime}$ & 131.5 & 131.5 & 131.6 & 131.6 \\
3 & 101.8 & 101.1 & 101.7 & 101.7 & $2^{\prime}$ & 103.4 & 102.4 & 103.5 & 102.2 \\
$3 \mathrm{a}$ & 121.9 & 122.2 & 122.0 & 122.0 & $3^{\prime}$ & 158.8 & 158.8 & 159.1 & 158.8 \\
4 & 120.9 & 121.0 & 120.9 & 116.1 & $4^{\prime}$ & 103.9 & 102.8 & 103.8 & 102.6 \\
5 & 117.2 & 116.5 & 117.2 & 124.3 & $5^{\prime}$ & 158.8 & 158.8 & 158.8 & 158.8 \\
6 & 151.2 & 150.8 & 151.2 & 158.1 & $6^{\prime}$ & 104.8 & 102.4 & 104.8 & 102.2 \\
7 & 98.4 & 98.5 & 98.4 & 92.3 & $1^{\prime \prime}$ & 100.8 & 100.2 & 100.8 & 97.4 \\
$7 \mathrm{a}$ & 153.8 & 154.6 & 153.9 & 154.2 & $2^{\prime \prime}$ & 72.4 & 73.8 & 73.3 & 73.5 \\
8 & 31.2 & 27.6 & 31.3 & 29.8 & $3^{\prime \prime}$ & 70.3 & 77.0 & 76.6 & 77.0 \\
9 & 67.4 & 73.4 & 68.1 & 88.9 & $4^{\prime \prime}$ & 68.0 & 70.3 & 69.7 & 70.1 \\
10 & 77.3 & 76.3 & 77.3 & 77.1 & $5^{\prime \prime}$ & 65.5 & 77.0 & 77.1 & 76.6 \\
11 & 25.8 & 25.8 & 25.8 & 23.4 & $6^{\prime \prime}$ & & 61.4 & 60.7 & 60.9 \\
12 & 20.3 & 21.3 & 20.4 & 21.8 & & & & & \\
\hline \multicolumn{7}{c}{ Measured at ${ }^{\text {a }} 125 \mathrm{MHz} \mathrm{or}^{\mathrm{b}} 150 \mathrm{MHz}}$. & & &
\end{tabular}

Measured at ${ }^{\text {a }} 125 \mathrm{MHz}$ or ${ }^{\mathrm{b}} 150 \mathrm{MHz}$.

The molecular formula of compound 4 was established to be $\mathrm{C}_{25} \mathrm{H}_{28} \mathrm{O}_{10}$ by HRESIMS, which showed the quasimolecular ion peak at $m / z 511.1589[\mathrm{M}+\mathrm{Na}]^{+}$(calcd for $\mathrm{C}_{25} \mathrm{H}_{28} \mathrm{O}_{10} \mathrm{Na}^{+}, 511.1575$ ). The ${ }^{1} \mathrm{H}$-NMR and ${ }^{13} \mathrm{C}-\mathrm{NMR}$ spectroscopic data (Tables 1 and 2) of 4 suggested that it was a stilbene glucoside similar to 2 and 3, except the dihydropyran ring. HMBC correlations between $\mathrm{H}_{2}-8$ (3.16, $3.35)$ and $C-4\left(\delta_{C} 116.1\right)$ and $C-6\left(\delta_{C} 158.1\right) ; H-9\left(\delta_{H} 4.75\right)$ and $C-5\left(\delta_{C} 124.3\right)$ and $C-6\left(\delta_{C} 158.1\right)$ were observed, and the aglycone of 4 was elucidated as moracin $\mathrm{O}$ [25]. The linkage of sugar was determined to be at the C-10 position, deduced from the HMBC correlation between $\mathrm{H}-1^{\prime \prime}\left(\delta_{\mathrm{H}} 4.42, \mathrm{~d}, J=7.8 \mathrm{~Hz}\right)$ and $C-10\left(\delta_{C} 77.1\right)$. Acid hydrolysis identified the aglycone as $(9 R)$-moracin $\mathrm{O}$ and the sugar as D-glucose. Therefore, the structure of 4 was established as (9R)-moracin O 10-O- $\beta$-D-glucopyranoside.

There was only one chiral carbon C-9 in aglycones of compounds 1-4. In order to determine their absolute configuration, compounds 1-4 were hydrolyzed by $\mathrm{HCl}$, and the aglycones were partitioned by EtOAc. After drying the EtOAc-soluble fraction in vacuo, the residue was dissolved in $\mathrm{MeOH}$ to determine the optical rotation. All aglycones showed negative optical rotation values (see Supplementary Materials), which confirmed that aglycones 1a-3a were (9R)-moracin P [38] and aglycone 4a was (9R)-moracin O [38,39].

Although the sugars were substituted at different position, the ECD (electronic circular dichroism) spectra of 1-4 and their aglycones 1a and $\mathbf{4 a}$ were quite similar (Figure 2). There were two Cotton effects in their ECD spectra. The broad negative Cotton effect over 280-340 nm was regarded as $\pi \rightarrow \pi^{*}$ transition from MO86 to MO87 of 2-benzylbenzofuran. The negative Cotton effect at $240 \mathrm{~nm}$ was generated by $\pi \rightarrow \pi^{*}$ transition from MO86 to MO90 of benzofuran moiety and $\pi \rightarrow \pi^{*}$ transition from MO86 to MO89 of benzyl moiety, according to the MO analysis in the calculated ECD of 1a (Supplementary Materials). It seemed that the chiral carbon on the rigid skeleton attached to the benzofuran affected the Cotton effect at $240 \mathrm{~nm}$ more than the chiral center on the flexible benzyl moiety, deduced from the similar ECD spectra of 1-4, 1a, and $\mathbf{4 a}$. 


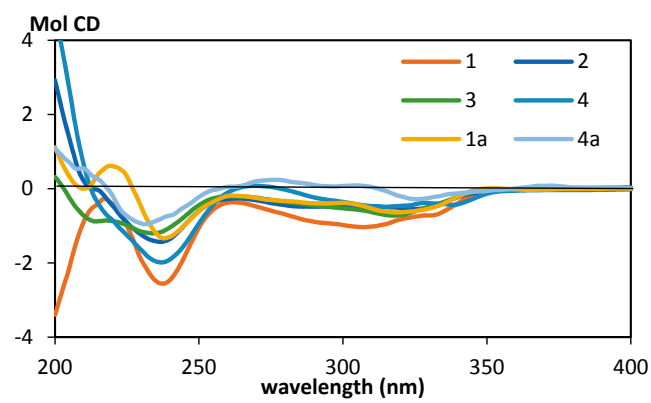

Figure 2. Electronic circular dichroism (ECD) spectra of 1-4, 1a, and $\mathbf{4 a .}$

\subsection{Neuroprotective Activities}

Twelve compounds were evaluated by the 3-(4,5-dimethylthiazol-2-yl)-2,5-diphenyltetrazolium bromide (MTT) assay for the neuroprotective effects against glutamate-induced cellular damage on the human neuroblastoma SK-N-SH cells (Table 3). Moracin O (5), R (7), and P (8) exhibited significant protection with $40 \%-60 \%$ of cell viability at the concentration of $10 \mu \mathrm{M}$. Norartocarpetin (13) and morusin (15) exhibited modest protection effects with about $20 \%$ cell viability. Oxyresveratrol (6) and sanggenon $\mathrm{C}(\mathbf{1 6})$ at the concentration of $10 \mu \mathrm{M}$ attenuated glutamate-induced toxicity weakly (about $12 \%$ cell viability), similar to resveratrol. It has been reported that moracin $\mathrm{O}(5)$ and moracin $\mathrm{P}(8)$ were promising drug candidates for cerebral ischemia and other neurodegenerative diseases due to their protective activities against oxygen-glucose deprivation (OGD)-induced cell death [40]. Therefore, we also tested the neuroprotective effects of compounds 1-5, 7-9 against OGD-induced damage and 3-nitropropionic acid (3-NP)-induced neuronal injury on human neuroblastoma SH-SY5Y cells using the MTT method. Our results demonstrated that only moracin O (5), P (8), and moracin P $3^{\prime}-O-\beta$-D-glucopyranoside (3) indicated weak neuroprotective activities against OGD-induced damage, and none of them protected cells from the 3-NP-induced damage (Table 3).

Table 3. Neuroprotective effects of compounds $(10 \mu \mathrm{M})$ from Cortex Mori Radicis against the injured neuron cells.

\begin{tabular}{cccc}
\hline Compounds & \multicolumn{3}{c}{ Cell Viability (\%) $^{\mathbf{a}}$} \\
\hline Injured reagent & $\mathrm{L}-\mathrm{Glu}^{\mathrm{b}}$ & $\mathrm{Na}_{2} \mathrm{~S}_{2} \mathrm{O}_{4} \mathrm{c}^{\mathrm{c}}$ & 3-NP $\mathrm{c}$ \\
Control & 100 & 100 & 100 \\
Injured control & $0.0^{\# \# \#, \mathrm{~d}}$ & $0.0 \# \#, \mathrm{e}$ & $0.0^{\# \# \#, \mathrm{f}}$ \\
Moracin P 3'-O- $\alpha$-L-arabinopyranoside (1) & $-5.0 \pm 2.6$ & $-0.4 \pm 1.3$ & - \\
Moracin P 9-O- $\beta$-D-glucopyranoside (2) & $-2.0 \pm 1.5$ & $4.4 \pm 1.34$ & - \\
Moracin P 3'-O- $\beta$-D-glucopyranoside (3) & $1.9 \pm 3.3$ & $7.1 \pm 2.52$ & - \\
Moracin O 10-O- $\beta$-D-glucopyranoside (4) & $-4.4 \pm 0.4$ & $-1.4 \pm 0.5$ & - \\
Moracin O (5) & $56.0 \pm 5.1^{* *}$ & $12.4 \pm 1.5$ & - \\
Oxyresveratrol (6) & $12.7 \pm 5.4$ & - & - \\
Moracin R (7) & $50.0 \pm 4.5^{* *}$ & $0.9 \pm 1.4$ & $-3.3 \pm 2.6$ \\
Moracin P (8) & $40.1 \pm 4.4 *$ & $9.0 \pm 2.1$ & $0.3 \pm 3.8$ \\
Mulberroside C (9) & $-6.0 \pm 2.0$ & $0.0 \pm 2.1$ & - \\
Norartocarpetin (13) & $21.7 \pm 3.9$ & - & - \\
Morusin (15) & $20.2 \pm 4.8$ & - & - \\
Sanggenon C (16) & $13.5 \pm 4.4$ & - & - \\
Resveratrol g & $12.0 \pm 2.4$ & - & - \\
\hline
\end{tabular}

a The cell viability was calculated as $100 \times$ (tested group - damaged group)/(control group - damaged group). The cell line was ${ }^{\mathrm{b}}$ SK-N-SH or ${ }^{\mathrm{c}}$ SH-SY5Y. The cell survival percentage was ${ }^{\mathrm{d}} 58.4 \pm 3.1 \%$, e $67.8 \% \pm 1.5 \%,{ }^{\mathrm{f}} 60.1 \%$ $\pm 1.8 \%$ compared with the control group. ${ }^{\mathrm{g}}$ Acted as positive control only in the glutamate-induced cell death assay. \#\#\# $p<0.001$ versus control group; ${ }^{*} p<0.05,{ }^{* *} p<0.01$ versus injured control group. 


\subsection{Postulating the Neuroprotective Pathway by Molecular Docking}

In order to further understand the possible mechanisms of the benzofuran stilbenes against glutamate-induced neuronal death, 10 glutamate receptors, including various ionotropic and metabotropic types, were selected from 64 Homo sapiens GluRs in the Protein Data Bank (PDB) website to study the ligand binding to these receptors in a molecular-docking method.

Among the selected glutamate receptors, the mGluR $13 \mathrm{KS} 9$ ) was the only one that could be docked with all active compounds $(5-8,13$, and 15$)$ as well as glutamic acid. In contrast, all of the inactive compounds $(\mathbf{1}-\mathbf{4}, \mathbf{9})$ could not be docked into the binding site of the $\mathrm{mGluR}_{1}(3 \mathrm{KS} 9)$. These results indicated that the neuroprotective activities of moracin $O(5), R(7)$, and $P(8)$, might be mediated by the GluR $_{1}$ pathway.

Molecular-docking results (Figure 3) showed each of the three ligands, moracin O (5), R (7), and $\mathrm{P}(8)$, had $\pi-\pi$ interaction between the aromatic plane and Trp 110, and three to four H-bonds between hydroxyl groups of the ligands and the residues of Arg 71, Arg 78, Tyr 236 (or Asp 208, Ser165, Thr188) in $\mathrm{mGluR}_{1}$, which indicated that the aromatic group and the hydroxyl group play an important role in the bindings.

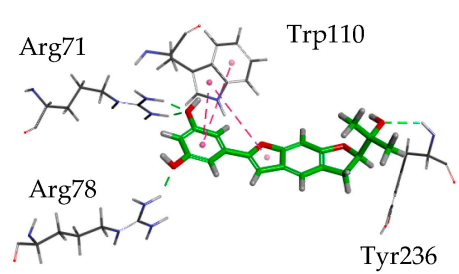

(a)

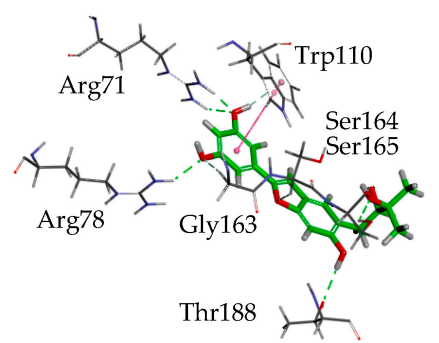

(b)

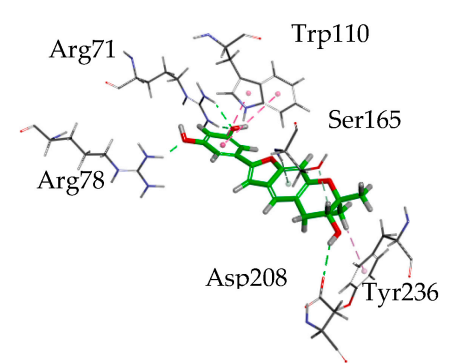

(c)

Figure 3. Binding models of moracin O (5), R (7), P (8) with the key residues of metabotropic glutamate receptor 1 ( $\mathrm{mGluR}_{1}$ ) (3KS9). (a) Moracin O; (b) Moracin R; (c) Moracin P.

\subsection{Analgesic Activities}

Although some compounds from the genus Morus exhibited promising neuroprotective activity, Morus species have been rarely used to treat neurodegenerative diseases or other CNS diseases. As mGlu receptors had been considered to be valid targets for chronic pain control due to their ability of modulating rather than mediating excitatory synaptic activity [41], it was reasonable to hypothesize that these neuroprotective isoprenylated stilbenes might be the active analgesic components of Cortex Mori Radicis.

The three most effective neuroprotective stilbenes—moracin O (5), R (7), P (8)—and reported [20] flavonoid morusin (15) were assayed with the analgesic test and paracetamol was a positive control. As predicted, both moracin $\mathrm{O}(5)$ and $\mathrm{P}(\mathbf{8})$, with cyclic structural moieties, demonstrated more than $95 \%$ of inhibitions of acetic acid-induced pain at $80 \mathrm{mg} / \mathrm{kg}$, which were as effective as morusin, much better than paracetamol. These results were consistent with the reported inhibition of morusin, which was about $73 \%$ at $60 \mathrm{mg} / \mathrm{kg}$ [20]. However, moracin R (7), which had an acyclic moiety, showed moderate inhibition (Table 4). 
Table 4. Analgesic effects of neuroprotective stilbenes on acetic acid-induced pain.

\begin{tabular}{cccc}
\hline Samples & Dosage (mg/kg, i.p.) & Mean Numbers of Writhes \pm SD & Inhibition Ratio (\%) \\
\hline Control & 0 & $17 \pm 6$ & - \\
Moracin O (5) & 80 & $0 \pm 1^{*}$ & $98 \%$ \\
Moracin R (7) & 80 & $5 \pm 3^{*}$ & $76 \%$ \\
Moracin P (8) & 80 & $1 \pm 1^{*}$ & $95 \%$ \\
Morusin (15) & 80 & $1 \pm 1^{*}$ & $95 \%$ \\
Paracetamol & 200 & $1 \pm 1^{*}$ & $95 \%$ \\
\hline \multicolumn{2}{r}{}
\end{tabular}

As compounds 1-4 and 9 were the glycosides of moracin $O(5)$ and $P(8)$, they might act as predrugs through oral administration, although they did not show neuroprotective effects in vitro.

\section{Materials and Methods}

\subsection{Instruments}

Melting points were determined on an XT5B melting point apparatus (Beijing Keyi Electric Light Instrument Factory, Beijing, China) and were uncorrected. Optical rotations were measured with a P-2000 polarimeter (Jasco, Tokyo, Japan). ECD spectra were recorded at room temperature with a J-815 spectropolarimeter (Jasco). UV spectra were collected in $\mathrm{MeOH}$ on a V-650 spectrophotometer (Jasco). IR spectra were recorded on a Nicolet 5700 spectrometer (Thermo, Madison, WI, USA) by the FT-IR transmission electron microscopy method. ${ }^{1} \mathrm{H}$ - and ${ }^{13} \mathrm{C}-\mathrm{NMR}$ spectra were acquired using a DD2-500 spectrometer (Agilent, Santa Clara, CA, USA) or an AVIIIHD 600 spectrometer (Bruker, Billerica, MA, USA). HRESIMS were recorded on a 1200 series LC / 6520 quadrupole time of flight (QTOF) spectrometer (Agilent). Column chromatography (CC) purification was performed using silica gel (160-200 mesh), Sephadex LH-20 (GE, Boston, MA, USA) and $C_{18}(50 \mu \mathrm{m}, \mathrm{YMC}$, Kyoto, Japan). $\mathrm{CC}$ fractions were analyzed by thin-layer chromatography (TLC) (silica gel $\mathrm{GF}_{254}$ ).

\subsection{Plant Material}

The Cortex Mori Radicis were bought from Anguo herb market, Hebei, China, which were collected from Hunan Province, China, in 2012. These samples were identified by Professor Lin Ma, Institute of Materia Medica, Chinese Academy of Medical Science and Peking Union Medical College, China. A voucher specimen (ID-S-2604) is deposited in the Institute of Materia Medica, Chinese Academy of Medical Science and Peking Union Medical College, China. The HPLC (high-performance liquid chromatography) profile of this plant material is in the Supplementary Materials.

\subsection{Animals}

Male ICR (Institute of Cancer Research) mice (18-22 g) from Vital River Laboratories (Beijing, China) were used in these experiments. The animals were housed in a soundproof room at an appropriate temperature $\left(25 \pm 1{ }^{\circ} \mathrm{C}\right)$ and humidity $(50 \% \pm 10 \%)$ for three days before the experiment. They were kept under a $12 \mathrm{~h}$ light/12 h dark cycle (light from 7:00 a.m. to 7:00 p.m.) with free access to food and water. Every effort was made to minimize the number of experimental animals and the discomfort that they might experience. All animals were treated humanely in compliance with the "Principles of Laboratory Animal Care" and the "Guide for the Care and Use of Laboratory Animals of Peking Union Medical College and Chinese Academy of Medical Sciences". All experimental protocols were approved by the Animal Care and Use Committee of the College (Approval NO. 00000251).

\subsection{Extraction and Isolation}

Powdered Cortex Mori Radicis (50 kg) were soaked with EtOH/ $\mathrm{H}_{2} \mathrm{O}(50: 50, v / v)$ for $24 \mathrm{~h}$ and percolated with $300 \mathrm{~L} \mathrm{EtOH} / \mathrm{H}_{2} \mathrm{O}(50: 50, v / v)$. Then, evaporation of the solvent under reduced 
pressure gave a liquid extract, which was suspended in $\mathrm{H}_{2} \mathrm{O}$ and partitioned with EtOAc. The EtOAc extract (ca. $1 \mathrm{~kg}$ ) was applied to a silica gel column (160-200 mesh, $2 \mathrm{~kg}$ ), with a gradient elution $\left(\mathrm{CHCl}_{3} / \mathrm{MeOH}=1: 0-1: 1, v / v\right)$ to yield fractions D1-D22. Fraction D7 and D8 was subjected to a silica gel column and eluted with an eluent $\left(\mathrm{CHCl}_{3} /\right.$ acetone $\left.=1: 0-1: 1, v / v\right)$ to give 15 subfractions. The fifth subfraction was purified by a Sephadex LH-20 column, eluted with $\mathrm{MeOH}$, to yield compound 15 (32 mg). The 8-12th subfraction was separated by MCI gel using a mobile phase of $\mathrm{MeOH}-\mathrm{H}_{2} \mathrm{O}$ and followed by preparative HPLC to afford compound 5 ( $25 \mathrm{mg}), 7(20 \mathrm{mg}), 8(53 \mathrm{mg}), \mathbf{1 3}(5 \mathrm{mg}), \mathbf{1 6}$ (15 mg), $\mathbf{1 7}(8 \mathrm{mg})$, and $\mathbf{1 8}(5 \mathrm{mg})$. Fraction D11 and D12 was applied to RP $\mathrm{C}_{18}$ column, this being eluted with an eluent $\left(\mathrm{MeOH} / \mathrm{H}_{2} \mathrm{O}\right)$ to give 11 subfractions. Compound $\mathbf{6}(2.3 \mathrm{~g})$ was precipitated from the third subfraction. The fourth subfraction was purified by preparative HPLC to yield compound 14 (320 mg). Fraction D13-D15 was applied to a Sephadex LH-20 column, using $\mathrm{MeOH} / \mathrm{H}_{2} \mathrm{O}$ as eluent, to give eight subfractions. The third subfraction was purified by a Sephadex LH-20 column, eluted $\mathrm{MeOH}$, and then purified by HPLC to yield compound 1 (7 mg), 2 (3 mg), 3 ( $2 \mathrm{mg})$, and 4 $(4 \mathrm{mg})$. The fifth subfraction was purified by a Sephadex LH-20 column and preparative HPLC, to yield compound $\mathbf{1 0}(2 \mathrm{mg}), \mathbf{1 1}(3 \mathrm{mg})$, and $\mathbf{1 2}(3 \mathrm{mg})$. The seventh subfraction was subjected to a silica gel column and eluted by petroleum ether/EtOAc (1:0-1:1) to yield compound $\mathbf{9}(10 \mathrm{mg})$. The retention times of all isolated compounds were determined by the HPLC profile in Supplementary Materials.

Moracin P 3'-O- $\alpha$-L-Arabinopyranoside (1). Brown powder, m.p. 135.6-137.4 ${ }^{\circ} \mathrm{C} ;[\alpha]_{\mathrm{D}}^{20}-65.9(c 0.1$, $\mathrm{MeOH}) ; \mathrm{UV}(\mathrm{MeOH}) \lambda_{\max }(\log \varepsilon) 219,320(3.54), 333 \mathrm{~nm} ; \mathrm{CD}(c 0.25, \mathrm{MeOH})[\theta]_{237.5}-8440,[\theta]_{307}$ -3409, [0] $]_{329.5}-2380$; IR $v_{\max } 3387,2979,2926,1605,1577,1461,1352,1173,1146,1108,1176,947$, 859, $799 \mathrm{~cm}^{-1} ;{ }^{1} \mathrm{H}$ - and ${ }^{13} \mathrm{C}-\mathrm{NMR}$ data, Tables 1 and 2; HRESIMS $\mathrm{m} / z$ 459.1663 [M + H ${ }^{+}$(calcd for $\left.\mathrm{C}_{24} \mathrm{H}_{27} \mathrm{O}_{9}{ }^{+}, 459.1650\right)$.

Moracin P 9-O- $\beta$-D-Glucopyranoside (2). Brown powder, m.p. $123.3-124.4{ }^{\circ} \mathrm{C} ;[\alpha]_{\mathrm{D}}^{20}-183.4(c 0.1$, $\mathrm{MeOH}) ; \mathrm{UV}(\mathrm{MeOH}) \lambda_{\max }(\log \varepsilon) 219,319(3.34), 333 \mathrm{~nm}$; CD $(c 0.25, \mathrm{MeOH})[\theta]_{236.5}-4724,[\theta]_{324}$ -1815; IR $v_{\max } 3358,2977,2930,1606,1579.7,1461.9,1354,1150,1107,1080,1036,947,845 \mathrm{~cm}^{-1} ;{ }^{1} \mathrm{H}-$ and ${ }^{13} \mathrm{C}-\mathrm{NMR}$, Tables 1 and 2; HRESIMS $m / z 511.1588[\mathrm{M}+\mathrm{Na}]^{+}$(calcd for $\mathrm{C}_{25} \mathrm{H}_{28} \mathrm{O}_{10} \mathrm{Na}^{+}$, 511.1575).

Moracin P 3'-O- $\beta$-D-Glucopyranoside (3). Brown powder, $[\alpha]_{\mathrm{D}}^{20}-47.6$ (c 0.1, MeOH); m.p. 136.3-137.2 ${ }^{\circ} \mathrm{C} ; \mathrm{UV}(\mathrm{MeOH}) \lambda_{\max }(\log \varepsilon) 219,321(3.28), 334 \mathrm{~nm} ; \mathrm{CD}\left(c\right.$ 0.25, MeOH) $[\theta]_{234}-3966,[\theta]_{317.5}-2390$; IR $v_{\max } 3341,2977,2927,1619.6,1576.6,1461.8,1352,1174,1142,1078,1023,996,850 \mathrm{~cm}^{-1} ;{ }^{1} \mathrm{H}-$ and ${ }^{13} \mathrm{C}-\mathrm{NMR}$ data, Tables 1 and 2; HRESIMS $m / z 511.1588[\mathrm{M}+\mathrm{Na}]^{+}$(calcd for $\mathrm{C}_{25} \mathrm{H}_{28} \mathrm{O}_{10} \mathrm{Na}^{+}$, 511.1575).

Moracin O 10-O- $\beta$-D-Glucopyranoside (4). Brown powder, m.p. $119.5-120.5{ }^{\circ} \mathrm{C} ;[\alpha]_{\mathrm{D}}^{20}-148.3(c 0.1$, $\mathrm{MeOH}) ; \mathrm{UV}(\mathrm{MeOH}) \lambda_{\max }(\log \varepsilon) 219,322(3.36), 336 \mathrm{~nm} ; \mathrm{CD}(c 0.25, \mathrm{MeOH})[\theta]_{237}-6551,[\theta]_{315}-1607 ;$ IR $v_{\max } 3349,2979,2922,1619,1578.8,1456.8,1359,1163,1084,1042,951,876,845 \mathrm{~cm}^{-1} ;{ }^{1} \mathrm{H}-$ and ${ }^{13} \mathrm{C}-\mathrm{NMR}$ data, Tables 1 and 2; HRESIMS $m / z 511.1589[\mathrm{M}+\mathrm{Na}]^{+}$(calcd for $\mathrm{C}_{25} \mathrm{H}_{28} \mathrm{O}_{10} \mathrm{Na}^{+}$, 511.1575).

\subsection{Acid Hydrolysis of Compounds 1-4}

Compounds 1-4 (ca. $0.5 \mathrm{mg}$ ) were dissolved in $0.5 \mathrm{~N} \mathrm{HCl}\left(0.1 \mathrm{~mL}\right.$ ) and heated at $90^{\circ} \mathrm{C}$ for $2 \mathrm{~h}$. The solution was neutralized with aqueous ammonia and partitioned with EtOAc $(0.2 \mathrm{~mL} \times 3)$. After drying the $\mathrm{H}_{2} \mathrm{O}$-soluble fraction in vacuo, the residue was dissolved in pyridine $(0.1 \mathrm{~mL})$ containing L-cysteine methyl ester hydrochloride $(0.5 \mathrm{mg})$ and heated at $60^{\circ} \mathrm{C}$ for $1 \mathrm{~h}$. A $0.1 \mathrm{~mL}$ solution of $o$-torylisothiocyanate $(0.5 \mathrm{mg})$ in pyridine was added to the mixture, which was heated at $60^{\circ} \mathrm{C}$ for $1 \mathrm{~h}$. The reaction mixture was directly analyzed by analytical HPLC under the following conditions: column was Grace Prevail $C_{18}(4.6 \times 250 \mathrm{~mm}, 5 \mu \mathrm{m}$, Grace, Deerfield, IL, USA); the mobile phase was acetonitrile and $50 \mathrm{mM} \mathrm{H}_{3} \mathrm{PO}_{4}$ (25:75); flow rate was $0.8 \mathrm{~mL} / \mathrm{min}$; wavelength was $250 \mathrm{~nm}$; column temperature was $35^{\circ} \mathrm{C}$. Under the above conditions, authentic D/L-glucose, D/L-arabinose gave HPLC peaks at $t_{R} 20.6 / 18.8$ and $24.0 / 22.3 \mathrm{~min}$, respectively. The $t_{R}$ of the sugars of the isolates obtained by acid hydrolysis gave similar results as those of standard sugars. 


\subsection{Neuroprotective Assay}

Human neuroblastoma SH-SY5Y cells were grown in Dulbecco's Modified Eagle's Medium (DMEM) (Sigma-Aldrich, St. Louis, MO, USA) containing 10\% fetal bovine serum (FBS), 100 U/mL penicillin/streptomycin. Cell cultures were incubated at $37{ }^{\circ} \mathrm{C}$ in a humid $5 \% \mathrm{CO}_{2} / 95 \%$ air environment. SK-N-SH cells were cultured in 96-well microplates at a density of $1 \times 10^{5}$ cells / well. Compounds were prepared in DMSO as $100 \mathrm{mM}$ stock solution. Glutamate and 3-NP were freshly prepared prior to each experiment. $\mathrm{Na}_{2} \mathrm{~S}_{2} \mathrm{O}_{4}$ was prepared in phosphate buffer solution (PBS) as $50 \mathrm{mM}$ stock solution, stored in a refrigerator at $-20{ }^{\circ} \mathrm{C}$ and kept away from light. The cells were preincubated with compounds for $4 \mathrm{~h}$, and then the cells were separately incubated with $30 \mathrm{mM}$ glutamate for $4 \mathrm{~h}, 5 \mathrm{mM} \mathrm{Na} \mathrm{S}_{2} \mathrm{O}_{4}$ with DMEM lacking D-glucose solution for $24 \mathrm{~h}$, and $10 \mu \mathrm{M}$ 3-NP solution for $24 \mathrm{~h}$. After the scheduled time, MTT solution $(5 \mathrm{mg} / \mathrm{mL})$ was added for another $4 \mathrm{~h}$ at $37^{\circ} \mathrm{C}$. MTT formazan crystals were solubilized by DMSO and spectrophotometrically measured at $570 \mathrm{~nm}$ (the max. emission wavelength of detected samples was at $410 \mathrm{~nm}$ ). All data presented in our study were obtained from at least three independent experiments and expressed as the mean \pm SEM (standard error of the mean). Significant differences between groups were compared using the one-way ANOVA procedure followed by a least significant difference (LSD) post hoc test using SPSS ver. 10.0 software (SPSS Inc., Chicago, IL, USA). The differences were considered statistically significant at $p<0.05$.

\subsection{Acetic Acid-Induced Abdominal Constrictions}

ICR mice ( $n=10$ each group) were pretreated intraperitoneally (i.p.) with the compounds $(80 \mathrm{mg} / \mathrm{kg})$ in a separate set or standard drug paracetamol $(200 \mathrm{mg} / \mathrm{kg})$ i.p. $30 \mathrm{~min}$ before acetic acid injection $(0.7 \%)$. Control animals received a similar volume of the appropriate vehicle $(10 \mathrm{~mL} / \mathrm{kg})$ used to dilute the compounds.

The mice were placed individually into glass beakers and 5 min were allowed to elapse. The mice were then observed for a period of $10 \mathrm{~min}$ and the number of writhes was recorded for each animal. For scoring purposes, a writhe was indicated by stretching of the abdomen with simultaneous stretching of at least one hind limb. The formula for computing percent inhibition was: average writhes in the control group minus writhes in the drug group divided by writhes in the control group times $100 \%$.

\subsection{Molecular Modeling}

Computational molecular modeling studies were carried out using Discovery Studio 4.1.0 (Accelrys, San Diego, CA, USA). All structures of glutamate receptors (2NZS, 1S50, 3UA8, 4F39, 4NF4, 3KS9, 5CNI, 5CNK, 5C5C, and 3LMK) were downloaded from the PDB website. The binding site was defined from the PDB site records. The screening of glutamate receptors was carried out by positioning the ligand in the binding site using CDocker [42], and evaluated by -CDocker energy. The interaction of ligand and receptor was further calculated using Flexible Docking [43] and the conformation of ligand and protein-binding site was evaluated by-CDocker interaction energy.

\section{Conclusions}

In summary, 4 new benzofuran-type stilbene glycosides (1-4) along with 14 known compounds were isolated from the traditional Chinese medicines, Cortex Mori Radicis. The new compounds were identified as moracin $\mathrm{P}$ glycosides and moracin $\mathrm{O}$ glycosides. Three isoprenylated benzofuran-type stilbenes, moracin $\mathrm{O}(5), \mathrm{R}(7)$, and $\mathrm{P}(8)$, showed significant neuroprotective activity against glutamate-induced cell death in SK-N-SH cells. The molecular-docking results indicated that the active stilbenes could be mediated by the $\mathrm{mGluR}_{1}$ pathway for their neuroprotective activities. As glutamate receptors may be implicated in persistent or chronic pain, we hypothesize that these neuroprotective isoprenylated stilbenes might be the active analgesic components of the genus Morus, and this opinion 
was confirmed by the inhibition of the acetic acid-induced pain by three stilbenes. Although the neuroprotective effect on glutamate-induced neuron death of benzofuran-type stilbenes such as moracin E was reported [44], this paper firstly postulated their $m_{G l u R_{1}}$ pathway and correlated the neuroprotective activity with analgesic activity, which was related with the traditional antirheumatic usage of Morus species. As compounds 1-4 and 9 were the glycosides of moracin O (5) and P (8), they may act as predrugs through oral administration, although they did not show neuroprotective effect in vitro.

As only two analgesic compounds were reported in Morus plants, we believe that our findings gave a new alternative method to discover and evaluate the analgesic components in Morus species.

Supplementary Materials: The Supplementary materials (copies of MS, UV, ECD, IR, and NMR spectra of compounds 1-4, calculated ECD of 1a, and HPLC profile of plant material) are available online at: http://www. mdpi.com/1420-3049/22/2/236/s1.

Acknowledgments: We gratefully acknowledge financial support from the CAMS Innovation Fund for Medical Sciences (CIFMS) No. 2016-I2M-3-011 and the Fundamental Scientific Research Fund of Institute of Materia Medica No. 2016ZX350012.

Author Contributions: Y.-N.W. analyzed the NMR and ECD data; M.-F.L., A.-Q.L., M.-P.X. and L.L. performed the isolation. W.-Z.H., R.-M.X., J.G. and L.-L.M. perform the activity experiments; J.-J.Z., Y.P., and X.-L.W. designed the activity experiments; J.-G.S. and S.-J.W. calculated the molecular docking and wrote the paper.

Conflicts of Interest: The authors declare no conflict of interest.

\section{References}

1. Abbas, G.M.; Abdel Bar, F.M.; Baraka, H.N.; Gohar, A.A.; Lahloub, M.F. A new antioxidant stilbene and other constituents from the stem bark of Morus nigra L. Nat. Prod. Res. 2014, 28, 952-959. [CrossRef] [PubMed]

2. Ahmad, A.; Gupta, G.; Afzal, M.; Kazmi, I.; Anwar, F. Antiulcer and antioxidant activities of a new steroid from Morus alba. Life Sci. 2013, 92, 202-210. [CrossRef] [PubMed]

3. Kapche, G.D.W.F.; Amadou, D.; Waffo Teguo, P.; Donfack, J.H.; Fozing, C.D.; Harakat, D.; Tchana, A.N.; Merillon, J.M.; Moundipa, P.F.; Ngadjui, B.T.; et al. Hepatoprotective and antioxidant arylbenzofurans and flavonoids from the twigs of Morus mesozygia. Planta Med. 2011, 77, 1044-1047. [CrossRef] [PubMed]

4. Lim, H.J.; Jin, H.G.; Woo, E.R.; Lee, S.K.; Kim, H.P. The root barks of Morus alba and the flavonoid constituents inhibit airway inflammation. J. Ethnopharmacol. 2013, 149, 169-175. [CrossRef] [PubMed]

5. Riviere, C.; Krisa, S.; Pechamat, L.; Nassra, M.; Delaunay, J.C.; Marchal, A.; Badoc, A.; Waffo-Teguo, P.; Merillon, J.M. Polyphenols from the stems of Morus alba and their inhibitory activity against nitric oxide production by lipopolysaccharide-activated microglia. Fitoterapia 2014, 97, 253-260. [CrossRef] [PubMed]

6. Sohn, H.Y.; Son, K.H.; Kwon, C.S.; Kwon, G.S.; Kang, S.S. Antimicrobial and cytotoxic activity of 18 prenylated flavonoids isolated from medicinal plants: Morus alba L., Morus mongolica Schneider, Broussnetia papyrifera (L.) Vent, Sophora flavescens Ait and Echinosophora koreensis Nakai. Phytomedicine 2004, 11, 666-672. [CrossRef] [PubMed]

7. Grienke, U.; Richter, M.; Walther, E.; Hoffmann, A.; Kirchmair, J.; Makarov, V.; Nietzsche, S.; Schmidtke, M.; Rollinger, J.M. Discovery of prenylated flavonoids with dual activity against influenza virus and Streptococcus pneumoniae. Sci. Rep. 2016, 6, 27156. [CrossRef] [PubMed]

8. Pethakamsetty, L.; Ganapaty, S.; Bharathi, K.M. Phytochemical and antimicrobial examination of the root extracts of Morus Indica. Int. J. Pharm. Sci. Rev. Res. 2013, 21, 75-80.

9. Fukai, T.; Oku, Y.; Hano, Y.; Terada, S. Antimicrobial activities of hydrophobic 2-arylbenzofurans and an isoflavone against vancomycin-resistant enterococci and methicillin-resistant Staphylococcus aureus. Planta Med. 2004, 70, 685-687. [CrossRef] [PubMed]

10. Lim, S.L.; Park, S.Y.; Kang, S.; Park, D.; Kim, S.H.; Um, J.Y.; Jang, H.J.; Lee, J.H.; Jeong, C.H.; Jang, J.H.; et al. Morusin induces cell death through inactivating STAT3 signaling in prostate cancer cells. Am. J. Cancer Res. 2015, 5, 289-299. [PubMed]

11. Zhu, J.J.; Yan, G.R.; Xu, Z.J.; Hu, X.; Wang, G.H.; Wang, T.; Zhu, W.L.; Hou, A.J.; Wang, H.Y. Inhibitory effects of (2'R)-2', $3^{\prime}$-dihydro-2'-(1-hydroxy-1-methylethyl)-2,6'-bibenzofuran-6, $4^{\prime}$-diol on mushroom tyrosinase and melanogenesis in B16-F10 melanoma cells. Phytother. Res. 2015, 29, 1040-1045. [CrossRef] [PubMed] 
12. Tan, Y.X.; Liu, C.; Chen, R.Y. New 2-arylbenzofurans with selective cytotoxicity from Morus wittiorum. Phytochem. Lett. 2012, 5, 419-422. [CrossRef]

13. Almeida, J.R.G.D.S.; Souza, G.R.; Araujo, E.C.D.C.; Silva, F.S.; Tolentino De Lima, J.; Ribeiro, L.A.D.A.; Nunes, X.P.; Barbosa Filho, J.M.; Quintans, L.J., Jr.; Viana Dos Santos, M.R. Medicinal plants and natural compounds from the genus Morus (Moraceae) with hypoglycemic activity: a review. In Glucose Tolerance; Chackrewarthy, S., Ed.; INTECH Open Access Publisher: Rijeka, Croatia, 2012; pp. 189-206.

14. Yang, Y.; Tan, Y.X.; Chen, R.Y.; Kang, J. The latest review on the polyphenols and their bioactivities of Chinese Morus plants. J. Asian Nat. Prod. Res. 2014, 16, 690-702. [CrossRef] [PubMed]

15. Naik, R.; Harmalkar, D.S.; Xu, X.; Jang, K.; Lee, K. Bioactive benzofuran derivatives: Moracins A-Z in medicinal chemistry. Eur. J. Med. Chem. 2015, 90, 379-393. [CrossRef] [PubMed]

16. Guan, Q.; Zhang, H. Study on anti-inflammatory action and analgesic effect of single antirheumatic Chinese Medicine. Chin. J. Clin. Ration. Drug Use 2012, 5, 6-7.

17. De, M.P.M.; Vilela, F.C.; Da, S.M.J.D.; Dos, S.M.H.; Alves da Silva, G.; Giusti Paiva, A. Antinociceptive effect of the extract of Morus nigra leaves in mice. J. Med. Food 2009, 12, 1381-1385.

18. Feng, T.T.; Xie, T.B.; Lin, B.; Zhao, Z.; Zhou, Y. Analgesic and anti-inflammatory effects of total flavonoids in Cortex Mori. Shizhen Guoyi Guoyao 2013, 24, 2580-2582.

19. Zhang, Z.; Shi, L. Anti-inflammatory and analgesic properties of cis-mulberroside A from Ramulus mori. Fitoterapia 2010, 81, 214-218. [CrossRef] [PubMed]

20. De Souza, M.M.; Bittar, M.; Cechinel-Filho, V.; Yunes, R.A.; Messana, I.; Delle Monache, F.; Ferrari, F. Antinociceptive properties of morusin, a prenylflavonoid isolated from Morus nigra root bark. Z. Naturforsch. C J. Biosci. 2000, 55, 256-260. [CrossRef]

21. Bardoni, R. Role of presynaptic glutamate receptors in pain transmission at the spinal cord level. Curr. Neuropharmacol. 2013, 11, 477-483. [CrossRef] [PubMed]

22. Bleakman, D.; Alt, A.; Nisenbaum, E.S. Glutamate receptors and pain. Semin. Cell Dev. Biol. 2006, 17, 592-604. [CrossRef] [PubMed]

23. Kim, Y.C. Neuroprotective phenolics in medicinal plants. Arch. Pharm. Res. 2010, 33, 1611-1632. [CrossRef] [PubMed]

24. Cossio Mora, F.P.; Arias Echeverria, L.L.; Vara Salazar, Y.I.; Aldaba Arevalo, E.; San Sebastian Larzabal, E.; Zubia Olascoaga, A. Polysubstituted Benzofurans and Medicinal Applications Thereof. European Patent 2388255A1, 23 November 2011.

25. Lee, H.Y.; Yum, J.H.; Rho, Y.K.; Oh, S.J.; Choi, H.S.; Chang, H.B.; Choi, D.H.; Leem, M.-J.; Choi, E.J.; Ryu, J.M.; et al. Inhibition of HCV replicon cell growth by 2-arylbenzofuran derivatives isolated from Mori Cortex Radicis. Planta Med. 2007, 73, 1481-1485. [CrossRef] [PubMed]

26. Dai, S.G.; Yu, D.Q.; Lu, Z.M.; Chen, R.Y. Isolation and identification of phenolic compounds from Morus macroura Miq. Zhongguo Yaowu Huaxue Zazhi 2006, 16, 102-105.

27. Kapche, G.D.W.F.; Fozing, C.D.; Donfack, J.H.; Fotso, G.W.; Amadou, D.; Tchana, A.N.; Bezabih, M.; Moundipa, P.F.; Ngadjui, B.T.; Abegaz, B.M. Prenylated arylbenzofuran derivatives from Morus mesozygia with antioxidant activity. Phytochemistry 2009, 70, 216-221. [CrossRef] [PubMed]

28. Tan, Y.X.; Liu, C.; Chen, R.Y. 2-arylbenzofuran derivatives from Morus wittiorum. Yaoxue Xuebao 2008, 43, 1119-1122.

29. Geng, C.A.; Ma, Y.B.; Zhang, X.M.; Yao, S.Y.; Xue, D.Q.; Zhang, R.P.; Chen, J.J. Mulberrofuran G and Isomulberrofuran G from Morus alba L.: Anti-hepatitis B Virus Activity and Mass Spectrometric Fragmentation. J. Agric. Food. Chem. 2012, 60, 8197-8202. [CrossRef] [PubMed]

30. Fukai, T.; Hano, Y.; Hirakura, K.; Nomura, T.; Uzawa, J.; Fukushima, K. Constituents of the cultivated mulberry tree. XXV. Constituents of root bark of Morus lhou Koidz. V. Structures of two natural hypotensive Diels-Alder type adducts, mulberrofurans F and G, from the cultivated mulberry tree (Morus lhou Koidz.). Chem. Pharm. Bull. 1985, 33, 3195-3204. [CrossRef] [PubMed]

31. Jeong, S.H.; Ryu, Y.B.; Curtis Long, M.J.; Ryu, H.W.; Baek, Y.S.; Kang, J.E.; Lee, W.S.; Park, K.H. Tyrosinase inhibitory polyphenols from roots of Morus lhou. J. Agric. Food. Chem. 2009, 57, 1195-1203. [CrossRef] [PubMed]

32. Nasrollahzadeh, M.; Sajadi, S.M.; Maham, M.; Salaryan, P.; Enayati, A.; Sajjadi, S.A.; Naderi, K. Optimal extraction method of phenolics from the root of Euphorbia condylocarpa. Chem. Nat. Compd. 2011, 47, 434-435. [CrossRef] 
33. Luo, S.D.; Nemec, J.; Ning, B.M. Anti-HIV flavonoids from Morus alba. Yunnan Zhiwu Yanjiu 1995, 17, 89-95.

34. Nomura, T.; Fukai, T.; Hano, Y.; Uzawa, J. Structure of sanggenon C, a natural hypotensive Diels-Alder adduct from Chinese crude drug "Sang-Bai-Pi" (Morus root barks). Heterocycles 1981, 16, 2141-2148. [CrossRef]

35. Nomura, T.; Fukai, T.; Hano, Y.; Uzawa, J. Structure of sanggenon D, a natural hypotensive Diels-Alder adduct from Chinese crude drug "Sang-Bai-Pi" (Morus root barks). Heterocycles 1982, 17, 381-389. [CrossRef]

36. Ni, G.; Zhang, Q.J.; Wang, Y.H.; Chen, R.Y.; Zheng, Z.F.; Yu, D.Q. Chemical constituents of the stem bark of Morus cathayana. J. Asian Nat. Prod. Res. 2010, 12, 505-515. [CrossRef] [PubMed]

37. Agrawal, P.K. NMR Spectroscopy in the structural elucidation of oligosaccharides and glycosides. Phytochemistry 1992, 31, 3307-3330. [CrossRef]

38. Dat, N.T.; Jin, X.; Lee, K.; Hong, Y.S.; Kim, Y.H.; Lee, J.J. Hypoxia-inducible factor-1 inhibitory benzofurans and chalcone-derived Diels-Alder adducts from Morus species. J. Nat. Prod. 2009, 72, 39-43. [CrossRef] [PubMed]

39. Kaur, N.; Xia, Y.; Jin, Y.; Dat, N.T.; Gajulapati, K.; Choi, Y.; Hong, Y.-S.; Lee, J.J.; Lee, K. The first total synthesis of moracin $\mathrm{O}$ and moracin $\mathrm{P}$, and establishment of the absolute configuration of moracin $\mathrm{O}$. Chem. Commun. 2009, 1879-1881. [CrossRef] [PubMed]

40. Lee, H.J.; Lyu, D.H.; Koo, U.; Lee, S.J.; Hong, S.S.; Kim, K.; Kim, K.H.; Lee, D.; Mar, W. Inhibitory effect of 2-arylbenzofurans from the Mori Cortex Radicis (Moraceae) on oxygen glucose deprivation (OGD)-induced cell death of SH-SY5Y cells. Arch. Pharm. Res. 2011, 34, 1373-1380. [CrossRef] [PubMed]

41. Chiechio, S.; Nicoletti, F. Metabotropic glutamate receptors and the control of chronic pain. Curr. Opin. Pharmacol. 2012, 12, 28-34. [CrossRef] [PubMed]

42. Wu, G.; Robertson, D.H.; Brooks, C.L., III; Vieth, M. Detailed analysis of grid-based molecular docking: A case study of CDOCKER-A CHARMm-based MD docking algorithm. J. Comput. Chem. 2003, 24, 1549-1562. [CrossRef] [PubMed]

43. Koska, J.; Spassov, V.Z.; Maynard, A.J.; Yan, L.; Austin, N.; Flook, P.K.; Venkatachalam, C.M. Fully automated molecular mechanics based induced fit protein-ligand docking method. J. Chem. Inf. Model. 2008, 48, 1965-1973. [CrossRef] [PubMed]

44. Jung, J.W.; Ko, W.M.; Park, J.H.; Seo, K.H.; Oh, E.J.; Lee, D.Y.; Lee, D.S.; Kim, Y.C.; Lim, D.W.; Han, D.; et al. Isoprenylated flavonoids from the root bark of Morus alba and their hepatoprotective and neuroprotective activities. Arch. Pharm. Res. 2015, 38, 2066-2075. [CrossRef] [PubMed]

Sample Availability: Samples of the compounds are available from the authors.

(C) 2017 by the authors; licensee MDPI, Basel, Switzerland. This article is an open access article distributed under the terms and conditions of the Creative Commons Attribution (CC BY) license (http:/ / creativecommons.org/licenses/by/4.0/). 